\title{
DEVICE FOR DISMANTLIING AND ASSEMBLING HARD-TO-SEPARATE MECHANICAL ASSEMBLIES ON MECHANICAL PLANTS
}

\author{
Nikola P. Žegarac \\ Serbian Academy of Inventors and Scientists, Belgrade, \\ Republic of Serbia \\ e-mail: zegaracnikola@vektor.net, \\ ORCID iD: (Dhttp://orcid.org/0000-0002-1766-8184
}

DOI: 10.5937/vojtehg65-10025

\begin{abstract}
FIELD: Mechanical Engineering, Energetics ARTICLE TYPE: Original Scientific Paper ARTICLE LANGUAGE: English

\section{Summary:}

The paper presents a new technical solution, a device for dismantling and assembling parts of mechanical plant components which are not easily separable. The device design allows wide possibilities of application in maintenance and repair of hydro power plants, thermal power plants, and diesel electric generators, in motor industry, shipbuilding industry and navy, aircraft industry, and turbines in process industry. The device for dismantling and assembling is universal and easy to use. Its small weight makes it easy to transport to locations with machine facilities.

Keywords: device for mounting and dismantling, hard-to-separate assemblies, mechanical installations, unit design, possibility of universal application of the device.

\section{Introduction}

During the years of maintenance and overhaul of mechanical plants, there has been a need to invent and design a device for assembling and dismantling hard-to-separate mechanical assemblies on mechanical plants. The device was supposed to have a wide range of applications: hydro power plants, thermal power plants, turbine systems in process industry, ships, reciprocating compressors, gas turbines, internal combustion engines, machine tools and other plants. This means that potential users are companies engaged in the production and maintenance of systems in: hydropower plants, motor industry, shipbuilding industry and 
the navy, aviation industry, turbine plants in process industry, manufacturers of gears, sliding and rolling bearings and other machine elements. The main part of the work shows the structure and the possibilities of the device application (Tehnička dokumentacija za Mini hidroelektrane Elektroprivrede Crne Gore,1964).

Description of the construction of the device for mounting and dismantling hard-to-separate mechanical assemblies

Figure 1 shows a device for mounting and dismantling hard-toseparate mechanical assemblies (Žegarac, 2004).
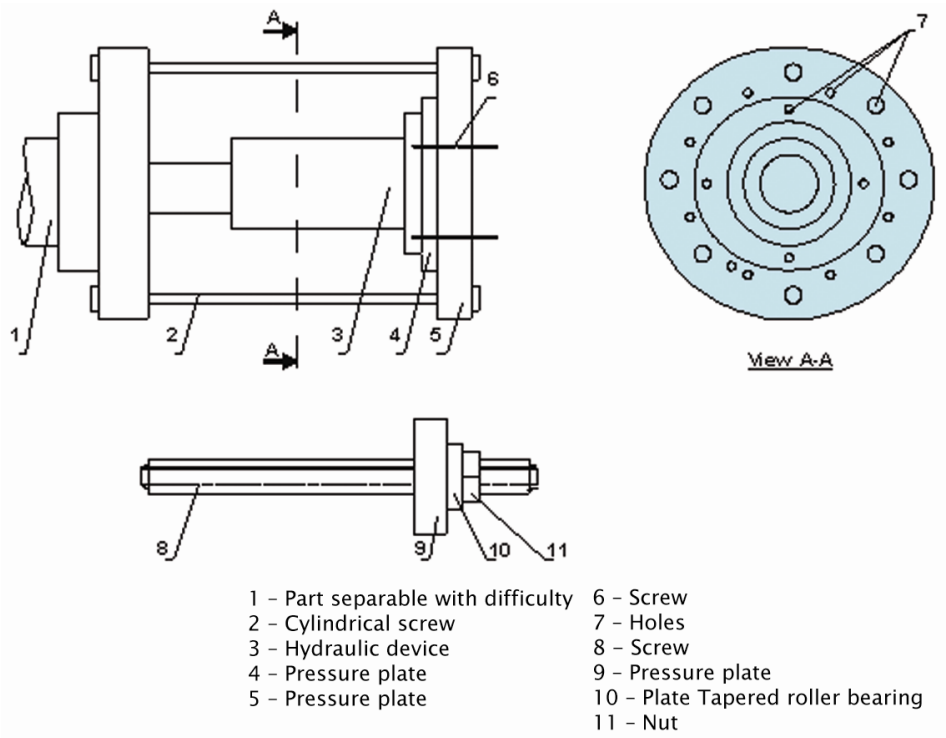

Figure 1 - Device for mounting and removing hard-to-separate components of mechanical constructions in mechanical systems

Puc. 1 - Монтажно-демонтажное устройство для сложно разбираемых деталей машиностроительного оборудования

Слика 1 - Уређај за демонтажу и монтажу тешко растављивих склопова на машинским постројењима

Position (1) in Fig.1 is a hard-to-separate mechanical part that is to be removed for replacement of other parts. Positions (2-5) are the parts of the device for removal. Position (2) indicates the anchor bolts, position (3) denotes the hydraulic device, positions (4) and (5) are pressure plates with different diameters, and position (6) represents the screws for joining pressure plates. Holes for anchor bolts are drilled at different diameters on the pressure plates thus enabling the device to be adapted to different dimensions of parts to be dismantled. The design and calculations of machine elements of the device were carried out under the design standard 
(Ognjanović, 2008), (Standardi za meterijale mašinskih elemenata, JUS M.B1.050, DIN 601, JUS M.B1.051, 1980).

Manual hydraulic devices of different capacities (10-50 tons) were used (Fig. 2) (Tehnička dokumentacija za hidraulične ručne dizalice Lincos, 2001), (Tehnička dokumentacija za hidraulučne ručne dizalice Sloga, 2002).

In the process of dismantling the parts, an autogenous welding set was used to heat the parts to be dismantled.

Positions (8-11) in Fig.1 indicate the parts to be dismantled. Position (8) denotes a threaded spindle which turns into the threaded hole at the head of the shaft or axle onto which the part is mounted. Position (9) is a pressure plate which pushes the part to be mounted into a specific position. Position (10) indicates a tapered roller bearing that reduces friction between the contact surfaces during assembly, and position (11) denotes a nut which pushes the conical bearing and the pressure plate on the threaded spindle, thus moving the part to be mounted. These operations require a considerable experience.
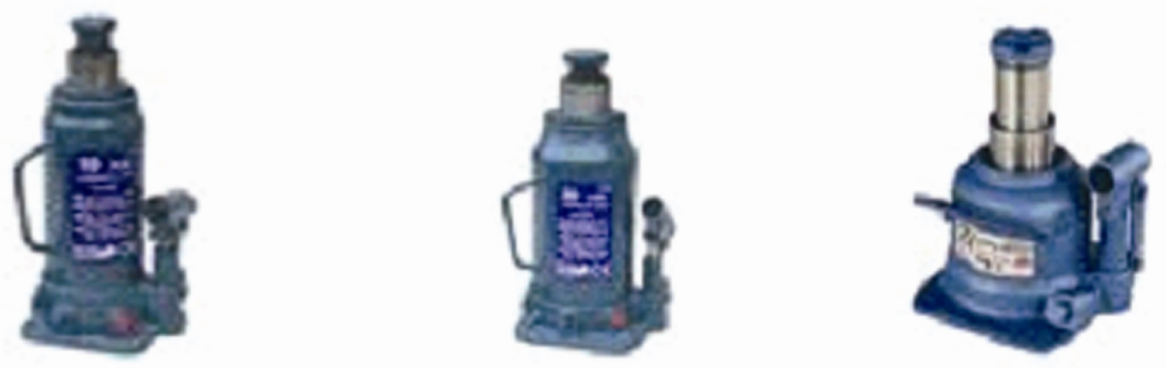

Figure 2 - Manual hydraulic cranes

Puc. 2 - Ручной гидравлический домкрат Слика 2 - Ручне хидрауличне дизалице

\section{Application of the device for dismantling and mounting hard-to-separate mechanical assemblies}

The device for dismantling and assembling difficult-to-detach parts has found its first application in the Electro Industry Montenegro and in some companies in the Republic of Serbia. In the Electro Industry Montenegro, it is used in maintenance and overhaul of mini hydro power plants. The operations of overhaul of hydro electric power plants have been significantly improved. This universal device is used in all 18 mini hydro electric power plants. 
One of these mini hydro power plants is shown in Fig. 3 (Žegarac, Zuber, 2004), (Žegarac, 2008).

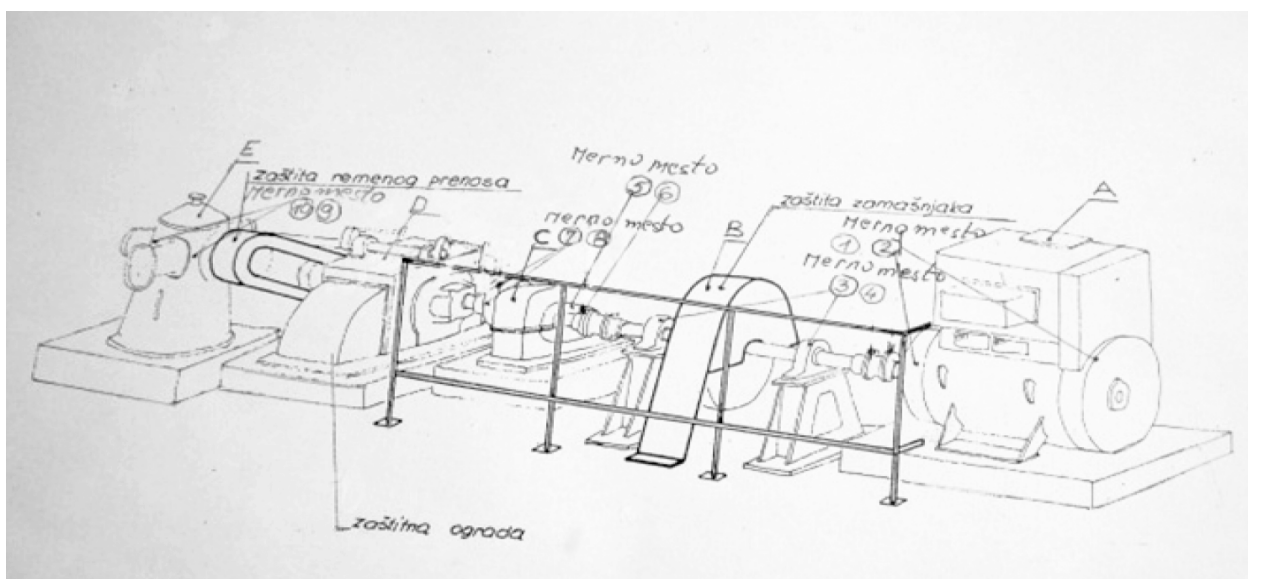

Figure 3 - Schematic representation of a mini hydro power plant Puc. 3 - Схематическое изображение сооружения мини-ГЭС

Слика 3 - Шематски приказ посторојења мини-хидроелектране

In Fig.3, hard-to-separate assemblies are labelled: the position (A) indicates the generator assemblies, the position (B) marks the flywheel assemblies, bearings, and the flexible couplings of the ARPEX typeGerman manufacturer Flender, the position $(C)$ is the multiplier with a flexible coupling type N-EUPEX A 480, German manufacturer Flender, the position (D) is the turbine part, and the position (E) denotes the turbine regulator. Fig. 4 presents the mounting of the metal parts of the flexible couplings N-EUPEX, onto one side of the multiplier set, and Fig. 5 presents the completed mounting of the ARPEX coupling onto the other side of the multiplier of the mini hydropower plant (Žegarac, 2009). 


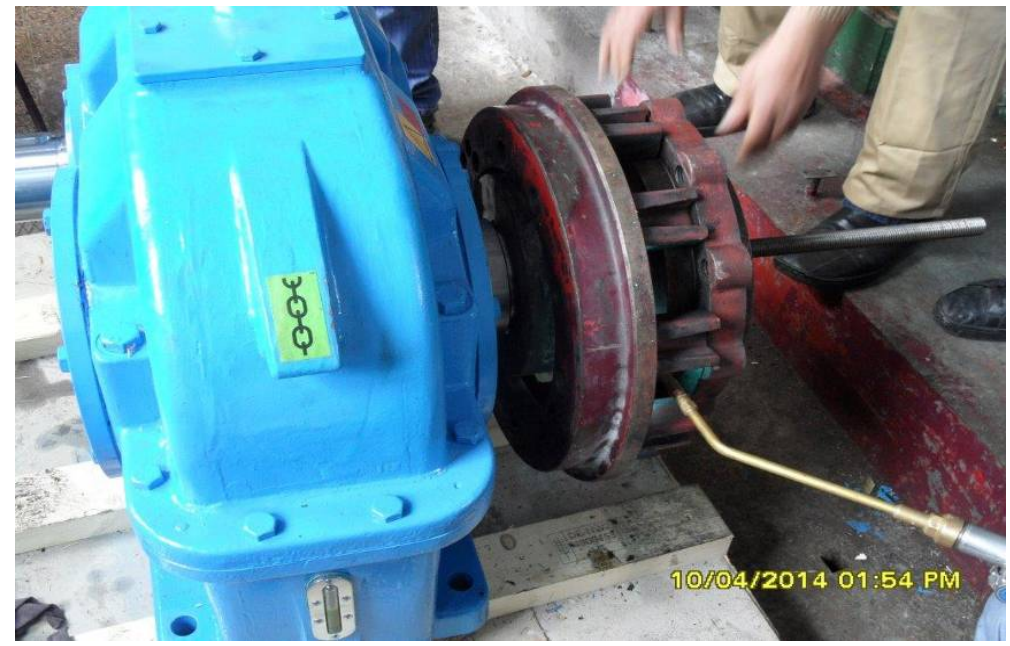

Figure 4-Mounting of the metal parts of the elastic coupling N-EUPEX onto the multiplier assembly

Puc. 4 - Монтаж стальных деталей упругой муфты к корпусу мультипликатора Слика 4 - Монтажа металних делова еластичне спојнице N-EUPEX на склоп мултипликатора

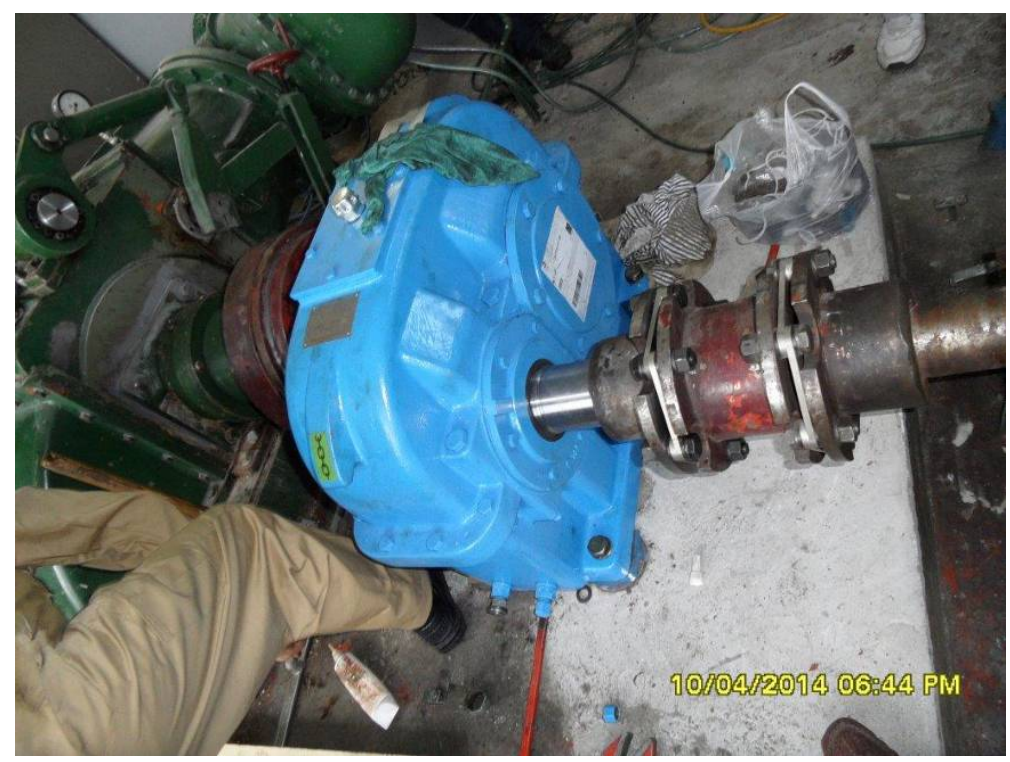

Figure 5-Display of the assembled ARPEX couplings on the multiplier of the hydro power plant Puc. 5 - Изображение завершенного монтажа муфрты Arpeх на мультипликаторе ГЭС Слика 5 - Приказ завршене монтаже Аrрех спојница на мултипликатор хидроелектране 
Fig.6 presents several characteristic hard-to-separate assemblies in mini hydro power plants (Tehnička dokumentacija Flender, 1979), (Tehnička dokumentacija Stromag, 1980).

...wenn Sie

elastische oder hochelastische,

drehstarre oder gelenkige,

schaltbare oder nichtschaltbare Wellen.

kupplungen

von $20 \mathrm{Nm}$ bis $10.000 .000 \mathrm{Nm}$

aus Stahl oder Gußeisen einsetzen.

ist Ihr Ansprechpartner..

FLENDER

A. FRIEDR. FLENDER GMBH

Kupplungswerk Mussum

Industriepark Bocholt

Schlavenhorst 100, DE- 46395 Bocholt

Tel.: (0 28 71) 92 - 28 68; Fax: (0 2871) 92 - 2579

E-mail: anja.blits@flender.com
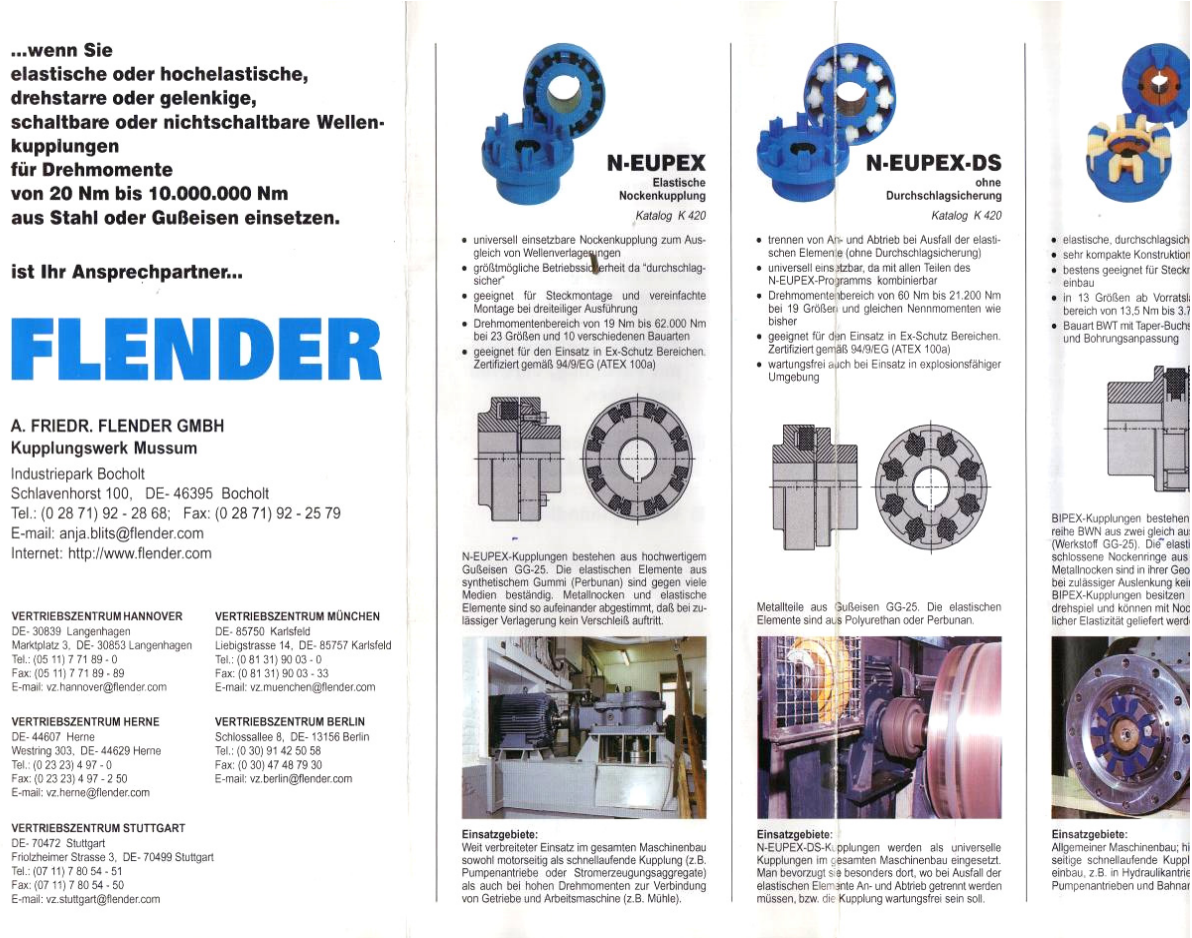

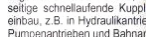

Figure 6 - Review of other typical hard-to-detach components of mini hydro power plants

Puc. 6 - Изображение прочих сложно разбираемых деталей мини-ГЭС

Слика 6 - Приказ осталих карактеристичних тешко растављивих склопова на минихидроелектранама

Fig.7 presents a mini hydro power plant in operation following the general overhaul (Žegarac, 2008). 


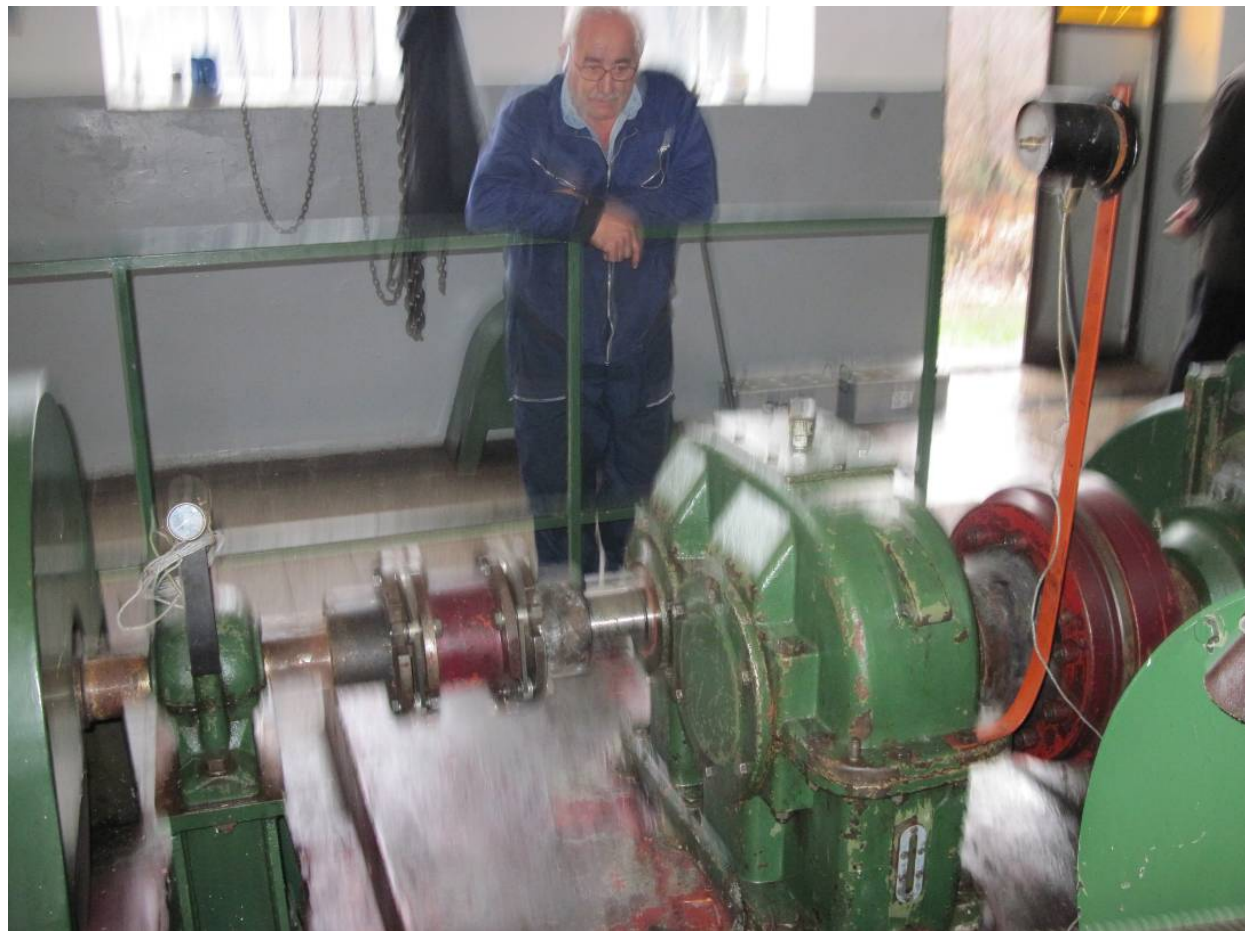

Figure 7 - A mini-hydro power plant in operation

Puc. 7 - Изображение мини-ГЭС в процессе эксплуатации

Слика 7 - Приказ мини-хидролектране у оперативном раду

\section{Conclusion}

The device for dismantling and assembling the parts of hard-toseparate mechanical assemblies on mechanical plants is an original and new technical solution (invention) in the maintenance and overhaul of mechanical systems, especially in off-road conditions where there are no other conditions for dismantling and mounting assemblies, such as specialized machine shops, overhaul institutes and others.

This device is portable, universal and very easy to use. It allows an easy, fast and efficient dismantling and assembling hard-to-separate parts large in size. Flanges or various types of metal hubs can have an external diameter up to $800 \mathrm{~mm}$, inner diameters may be up to $250 \mathrm{~mm}$, the size of the overlap (dosed components) to the axle or shaft may be up to 0.025 $\mathrm{mm}$, and the length of engagement work on the axle can be up to $300 \mathrm{~mm}$. This means that these parts are very complicated to disassemble and re- 
assemble. The device design is such that it prevents damage to parts during disassembling and reassembling.

The device has a wide range of applications. In the Electro Industry Montenegro, it is used to maintain mini hydroelectric power plants. In the Republic of Serbia, it is often used in repair of diesel electric generators for electric power supply backup. The users of diesel generating sets are many firms: Air Traffic Control, Airport Belgrade, Air Serbia, the Serbian Army and many other companies.

The application of this device has improved the technology of maintenance of mechanical installations.

\section{References}

Ognjanović, M., 2008, Mašinski elementi, knjiga I, II Mašinski fakultet Beograd.

Standardi za meterijale mašinskih elemenata (JUS M.B1.050, DIN 601, JUS M.B1.051), 1980.

Tehnička dokumentacija za hidraulične ručne dizalice Lincos, 2001. Beograd.

Tehnička dokumetacija za hidraulučne ručne dizalice Sloga, 2002. Nova Varoš.

Tehnička dokumentacija za Mini hidroelektrane Elektroprivrede Crne Gore,1964.

Tehnička dokumetacija Flender, 1979, Bocholt.

Tehnička dokumetacija Stromag, 1980, Dortmund.

Žegarac, N., 2004, Uređaj za demontažu i montažu delova teško rastavljivih sklopovima na mašinskim postrojenjima.

Žegarac, N., 2008, Izveštaj o merenju vibracija nakon generalnog remonta u MHE Rijeka Crnojevića.

Žegarac, N., 2009, Izveštaj o merenju i analizi vibracija nakon generalnog remonta MHE Podgor.

Žegarac, N., Zuber, N. 2004, Merenje i analiza vibracija nakon generalog remonta u MHE Podgor.

МОНТАЖНО-ДЕМОНТАЖНОЕ УСТРОЙСТВО ДЛЯ СЛОЖНО

РАЗБИРАЕМЫХ ДЕТАЛЕЙ МАШИНОСТРОИТЕЛЬНОГО

ОБОРУДОВАНИЯ

Никола П. Жегарац

Сербская академия изобретателей и ученых, Белград,

Республика Сербия 
ОБЛАСТЬ: машиностроение, энергетика

ВИД СТАТЬИ: оригинальная научная статья

ЯЗЫК СТАТЬИ: английский

\section{Резюме:}

В данной работе описаны новое технологическое решение, монтажно-демонтажное устройство для сложно разбираемых деталей. Благодаря своей конструкции, данное устройство имеет широкие возможности применения в области содержания и ремонта инженерных сооружений, таких как: ГЭС, ТЭС, дизельных электростанций, моторной промышленности, турбинных сооружений, а также в процессном производстве. Монтажно-демонтажное устройство отличается универсальностью, простотой в применении, легкостью веса, которая в свою очередь, способствует мобильности и легкому переносу на объекты.

Ключевые слова: монтажно-демонтажное устройство, сложно разбираемое оборудование, инженерные сооружения, конструкция устройства, универсальность применения устройства.

\section{УРЕЂАЈ ЗА ДЕМОНТАЖУ И МОНТАЖУ ДЕЛОВА ТЕШКО РАСТАВЉИВИХ МАШИНСКИХ СКЛОПОВА НА МАШИНСКИМ ПОСТРОЈЕЊИМА}

Никола П. Жегарац

Српска академија изумитеља и научника, Београд, Република Србија

ОБЛАСТ: машинство, енергетика

ВРСТА ЧЛАНКА: оригинални научни чланак

ЈЕЗИК ЧЛАНКА: енглески

\section{Сажетак:}

У раду је приказано ново техничко решење - уређај за демонтажу и монтажу делова тешко растављивих склопова на машинским постројењима. Његова конструкција омогућава широке могућности примене у одржавању и ремонту хидоелектрана, термоелектрана и дизел електроагрегата.Такође, може се применити у моторној и бродограђевинској индустрији, као и морнарици, авио-индустрији и код турбинских постројења у процесној индустрији. Уређај за демонтажу и монтажу је универзалан и лако се користи. Захваљујући својој малој тежини лако се преноси до локација где се налазе машинска постројења.

Кључне речи: уређај за демонтажу и монтажу, тешко растављиви склопови, машинска постројења, конструкција уређаја, универзална могућност примене уређаја. 
Paper received on / Дата получения работы / Датум пријема чланка: 19. 01. 2016. Manuscript corrections submitted on / Дата получения исправленной версии работы / Датум достављања исправки рукописа: 27. 03. 2016.

Paper accepted for publishing on / Дата окончательного согласования работы / Датум коначног прихватања чланка за објављивање: 01. 04. 2016.

(C) 2017 The Author. Published by Vojnotehnički glasnik / Military Technical Courier (www.vtg.mod.gov.rs, втг.мо.упр.срб). This article is an open access article distributed under the terms and conditions of the Creative Commons Attribution license (http://creativecommons.org/licenses/by/3.0/rs/).

(c) 2017 Автор. Опубликовано в «Военно-технический вестник / Vojnotehnički glasnik / Military Technical Courier» (www.vtg.mod.gov.rs, втг.мо.упр.срб). Данная статья в открытом доступе и распространяется в соответствии с лицензией «Creative Commons» (http://creativecommons.org/licenses/by/3.0/rs/).

() 2017 Аутор. Објавио Војнотехнички гласник / Vojnotehnički glasnik / Military Technical Courier (www.vtg.mod.gov.rs, втг.мо.упр.срб). Ово је чланак отвореног приступа и дистрибуира се у складу са Creative Commons licencom (http://creativecommons.org/licenses/by/3.0/rs/). 